\title{
Purification and Some Properties of Two Forms of Chitinase from Mycelial Cells of Mucor rouxii
}

\author{
By MARIO PEDRAZA-REYES ${ }^{1}$ AND EVERARDO LOPEZ-ROMERO ${ }^{1,2 *}$ \\ ${ }^{1}$ Instituto de Investigacion en Biologia Experimental, Facultad de Quimica, Universidad de \\ Guanajuato, Apartado Postal 187, Guanajuato, Gto 36000, Mexico \\ ${ }^{2}$ Departamento de Genetica y Biologia Molecular, Centro de Investigacion y de Estudios \\ Avanzados del IPN, Mexico
}

(Received 13 June 1988; revised 11 August 1988; accepted 19 September 1988)

Chitinase activity was measured in extracts of mycelial cells of Mucor rouxii as a function of the culture age. There was a peak of specific activity at the mid-exponential phase of growth $(10 \mathrm{~h})$, which paralleled chitin synthase activity. An additional peak of chitinase with higher specific activity was detected in $4 \mathrm{~h}$ cultures, which coincided with the onset of germination. Purification of chitinase activities from the cytoplasm revealed two enzymes, I and II, with different molecular mass and ionic charge. Antibodies induced with chitinase I did not crossreact with chitnase II. Both enzymes digested nascent chitin preferentially over preformed chitin, yielding diacetylchitobiose as the sole product of hydrolysis.

\section{INTRODUCTION}

It is commonly accepted that lytic enzymes play essential roles in the life cycle of fungi. They have been implied in apical growth, wall softening during hyphal branching, germination, degradation of septa for the mobilization of nuclei and hyphal fusions (Bartnicki-Garcia, 1973; Rosenberger, 1979; Wessels, 1986; Gooday et al., 1986). The unitary model of apical wall growth as formulated by Bartnicki-Garcia (1973) postulates that the ordered growth of the wall at the hyphal apex is the result of a very delicate balance of lysis and synthesis of wall polymers. For the maintenance of this balance, he proposed that the gradient of wall synthesis in the apical dome must be accompanied by a parallel gradient of lytic activity. Several pieces of evidence, mostly indirect, either support (Bartnicki-Garcia \& Lippman, 1972; Lopez-Romero et al., 1982; Humphreys \& Gooday, 1984a, b) or counter (Polacheck \& Rosenberger, 1978; Rosenberger, 1979) the model proposed by Bartnicki-Garcia.

Chitin, a homopolymer of $N$-acetyl-D-glucosamine (GlcNAc), is the major component of fungal walls (Bartnicki-Garcia, 1968). Thus, chitinase activity in these organisms should have physiological implications in hyphal growth and morphogenesis. Chitinase activity has been described in different subcellular fractions of several fungi (for reviews see Gooday et al., 1986; Cabib, 1987). A substance that interfered with chitin biosynthesis in vitro was detected in cellfree extracts of mycelial (McMurrough \& Bartnicki-Garcia, 1973) and yeast cells (LopezRomero et al., 1978) of Mucor rouxii. Further analysis on the mode of action of the inhibitory protein from yeast cells revealed that it was a chitinase (Lopez-Romero et al., 1982). Recently, we have described the presence of chitinolytic activity in the cytosol, a mixed membrane fraction and in the cell wall from mycelial cells of $M$. rouxii (Chagolla et al., 1987).

Abbreviations: UDP-GIcNAc, uridine 5'-diphospho- $N$-acetyl-D-glucosamine; GlcNAc, $N$-acetyl-Dglucosamine; PMB, phosphate/magnesium buffer; 3,4-DNP-TNAC, 3,4-dinitrophenol-tetra- $N$-acetyl- $\beta$-Dchitotetraoside. 
In this paper we describe the expression of chitinase activity during the growth cycle of $M$. rouxii and the isolation of two forms of chitinase from the cytosol of the fungus.

\section{METHODS}

Organism and culture conditions. Mucor rouxii IM-80 (ATCC 24905) from our stock collection was used for this study. To propagate the organism in the mycelial form, 2-litre Erlenmeyer flasks containing $650 \mathrm{ml}$ YPG medium (Bartnicki-Garcia \& Nickerson, 1962) were inoculated with spores $\left(5 \times 10^{5} \mathrm{ml}^{-1}\right)$ obtained as described by RuizHerrera \& Bartnicki-Garcia (1976). The flasks were shaken aerobically at 120 r.p.m. for $10 \mathrm{~h}$ at $28^{\circ} \mathrm{C}$.

Preparation of cell-free extracts. The mycelial cells were filtered through Whatman no. 1 paper on a Buchner filter unit, washed with $500-700 \mathrm{ml}$ phosphate/magnesium buffer (PMB; $50 \mathrm{mM}-\mathrm{KH}_{2} \mathrm{PO}_{4} / \mathrm{NaOH}, \mathrm{pH} 6.5$, containing $10 \mathrm{mM}-\mathrm{MgCl}_{2}$ ) and resuspended in the same buffer. About $20 \mathrm{ml}$ of the resuspended cells were mixed with an equal volume of glass beads (0.45-0.50 mm diameter) and broken in an MSK cell homogenizer (Braun) for $60 \mathrm{~s}$ while cooling with a stream of $\mathrm{CO}_{2}$. The resulting whole-cell homogenate, which was used in some experiments to measure chitin synthetase and chitinase activities, was centrifuged at $6500 \mathrm{~g}$ for $5 \mathrm{~min}$ to remove cell walls and unbroken cells. The cell-wall-free supernatant was centrifuged at $68000 \mathrm{~g}$ for $60 \mathrm{~min}$; the sediment was discarded and the supernatant (cytosol) was used for the purification of chitinases.

Purification of chitinases. Unless otherwise stated, the following steps were done at $4^{\circ} \mathrm{C}$. Ammonium sulphate, dissolved in PMB, was added to the $68000 \mathrm{~g}$ supernatant to give $60 \%$ saturation and, after $60 \mathrm{~min}$ of gentle shaking, the precipitate was collected by centrifugation at $3000 \mathrm{~g}$ for $10 \mathrm{~min}$. The precipitate was redissolved in PMB and exhaustively dialysed against the same buffer. This fraction $(\mathrm{P}-60 ; 7-9 \mathrm{ml})$ was layered on a Bio-Gel P-100 gel filtration column $(2 \times 130 \mathrm{~cm})$, equilibrated and eluted with PMB. Fractions of $5.0 \mathrm{ml}$ were collected. Chitinase activity on nascent chitin (see below) and UV absorbance at $280 \mathrm{~nm}$ were measured. Most active fractions were pooled and reprecipitated with $70 \%$ saturated ammonium sulphate as before. The precipitate was collected, resuspended in PMB and dialysed as described above. This fraction (P-70), containing both chitinases, was subjected to ion-exchange chromatography in a column $(2.5 \times 17.5 \mathrm{~cm})$ of DEAE Bio-Gel A equilibrated with $5 \mathrm{mM}-\mathrm{KH}_{2} \mathrm{PO}_{4} / \mathrm{NaOH}$ buffer, $\mathrm{pH} 6.5$, containing $10 \mathrm{mM}-\mathrm{MgCl}_{2}$. The column was washed with $170 \mathrm{ml}$ of the same buffer and then eluted with a linear gradient of $\mathrm{NaCl}$ from 0 to $0.4 \mathrm{M}$ at a flow rate of $40 \mathrm{ml} \mathrm{h}^{-1}$.

Chitin synthase assay. The standard incubation mixture contained : $0.4 \mathrm{~mm}{ }^{14} \mathrm{C}$-labelled uridine $5^{\prime}$-diphospho- $\mathrm{N}$ acetyl-D-glucosamine (UDP-GlcNAc; $0.25 \mathrm{Ci} \mathrm{mol}^{-1} ; 9.25 \mathrm{GBq} \mathrm{mol}^{-1}$ ), $20 \mathrm{mM}$-GicNAc, $0.2 \mathrm{mM}$-ATP, $10 \mathrm{mM}$ $\mathrm{MgCl}_{2}, 0.2 \mathrm{mg}$ of the acid protease rennilase, the enzyme fraction and $50 \mathrm{mM}-\mathrm{KH}_{2} \mathrm{PO}_{4} / \mathrm{NaOH}$ buffer, $\mathrm{pH} 6.5$, in a total volume of $50 \mu \mathrm{l}$. After $60 \mathrm{~min}$ at $24^{\circ} \mathrm{C}$, the reaction was stopped with a drop of glacial acetic acid and radioactivity incorporated into chitin was measured either by a filtration method as described by Ruiz-Herrera \& Bartnicki-Garcia (1976) or by descending paper chromatography using a solvent of isoamyl alcohol/pyridine/water $(1: 1: 0 \cdot 8$, by vol.) as previously described (Lopez-Romero et al., 1982). Chitin synthase activity was expressed as nmol GlcNAc incorporated into chitin $\mathrm{min}^{-1}$. For this and all other enzymes, specific activity is given in units (mg protein) $)^{-1}$. Protein was determined by the Lowry method.

Source of chitin synthase. Chitin synthase used for the assay of chitinase activity on nascent chitin was obtained as follows. About $10 \mathrm{ml}$ of the cytosol obtained as described above was subjected to gel chromatography on a column $(2 \times 30 \mathrm{~cm})$ of Bio-Gel A-5m equilibrated and eluted with PMB. Fractions corresponding to the void volume, enriched in chitin synthase activity, were pooled and used as the source of the enzyme.

Chitinase assay. Chitinase activity was measured against either nascent or preformed chitin as previously described (Lopez-Romero et al., 1982). In the first case, chitinase was included in the standard chitin synthase assay mixtures. The decrease in radioactivity incorporated into chitin compared to a control was taken as a measure of chitinase activity, which was expressed in units defined as the amount of enzyme that hydrolysed $50 \%$ of nascent chitin in $60 \mathrm{~min}$. To measure chitinase activity against preformed chitin, 5000 or 10000 c.p.m. (2.3$4.6 \mu \mathrm{g}$ ) of $\left[{ }^{14} \mathrm{C}\right]$ chitin prepared by chemical acetylation of chitosan with $\left[{ }^{14} \mathrm{C}\right]$ acetic anhydride (Hirano et al., 1976) was incubated with the chitinase-containing solutions in a total volume of $0.5 \mathrm{ml}$ in PMB. After $12 \mathrm{~h}$ at $30^{\circ} \mathrm{C}$, an equal volume of $90 \%(\mathrm{v} / \mathrm{v})$ ethanol/water was added and the samples were centrifuged in an Eppendorf centrifuge for $5 \mathrm{~min}$. Radioactivity released to the supernatant was taken as a measure of chitinase activity. In some experiments, 3,4-dinitrophenol-tetra- $N$-acetyl- $\beta$-D-chitotetraoside (3,4-DNP-TNAC) was also used as a substrate to assay chitinase activity, as described by Humphreys \& Gooday (1984a). In this case, one unit of chitinase activity was the amount of enzyme that released an amount of dinitrophenolate equivalent to an absorbance of 0.01 at $400 \mathrm{~nm}$ in $1 \mathrm{~min}$.

Preparation and specificity of antibodies. Rabbit antiserum to purified chitinase I (see below) was induced by four subcutaneous injections (at 2-week intervals) of $80-90 \mu \mathrm{g}$ of antigen emulsified in 1.0 ml Freund's complete adjuvant (first injection) and Freund's incomplete adjuvant (second to fourth injections). The IgG fractions of the immune and preimmune sera were obtained by precipitation with ammonium sulphate ( $50 \%$ saturation). The precipitate was collected by centrifugation at $6500 \mathrm{~g}$ for $10 \mathrm{~min}$, redissolved in PBS $(0.15 \mathrm{M}$-sodium chloride, $0.15 \mathrm{M}$-sodium phosphate, $\mathrm{pH} 7 \cdot 2$ ) and dialysed against the same buffer for $24 \mathrm{~h}$ at $4{ }^{\circ} \mathrm{C}$. The immunoglobulin 
fraction was distributed in aliquots and stored at $-70^{\circ} \mathrm{C}$. The titre of antibodies in the $\operatorname{IgG}$ fraction was determined by the ELISA test (Engvall \& Perlmann, 1972) using chitinase I from DEAE Bio-Gel A chromatography as the antigen $(0.6 \mu \mathrm{g}$ per well) and alkaline-phosphatase-conjugated goat anti-rabbit IgG (diluted 1 in 1000) as a secondary antibody. Specificity of antibodies was assessed by the immunoblot method. Accordingly, proteins in samples of chitinase I and II obtained after Bio-Gel P-100 chromatography were separated by SDS-PAGE as described below. The polypeptides were electrophoretically transferred to nitrocellulose membranes $(0.45 \mu \mathrm{m}$, Schleicher \& Schüll) according to the method of Towbin et al. (1979). After transfer, the membranes were blocked with $0.1 \%$ gelatin in PBS for $1 \mathrm{~h}$. After washing with PBS (four times, 15 min each), membrane strips were reacted for $2 \mathrm{~h}$ with preimmune or immune IgG diluted 1 in 10 in PBS/Tween (PBS containing 0.05\% Tween 20). Strips were washed in PBS/Tween and incubated for $2 \mathrm{~h}$ with peroxidaseconjugated goat anti-rabbit IgG diluted 1 in 1000 in PBS/Tween. After further washing in PBS/Tween, strips were immersed in a substrate solution containing $15 \mathrm{mg} 3,3^{\prime}$-diaminobenzidine and $0.17 \mathrm{ml} 3 \%(\mathrm{v} / \mathrm{v})$ hydrogen peroxide in $50 \mathrm{ml} 50 \mathrm{mM}-\mathrm{Tris} / \mathrm{HCl}$ buffer, $\mathrm{pH} \mathrm{7.4,} \mathrm{and} \mathrm{inspected} \mathrm{for} \mathrm{immunoreaction} \mathrm{bands} \mathrm{after} 20 \mathrm{~min}$.

$S D S-P A G E$. This was done on a continuous $10 \%(\mathrm{w} / \mathrm{v})$ gel with buffers and conditions essentially as described by Laemmli (1970). Chitinase samples were combined with half the volume of a solubilizing mixture containing $7 \%$ (w/v) SDS, 35\% (v/v) glycerol, $1.4 \%$ (v/v) 2-mercaptoethanol, $0.035 \%$ bromophenol blue (tracking dye) and $0.3 \mathrm{M}$ Tris/HCl, $\mathrm{pH}$ 6.8. The mixtures were heated in a boiling water bath for $5 \mathrm{~min}$ and applied to $1 \mathrm{~mm}$ thick slab gels. A constant current of $15 \mathrm{~mA}$ per gel was applied during stacking and increased to $25 \mathrm{~mA}$ per gel until the tracking dye was about $1 \mathrm{~cm}$ from the edge. Polypeptide bands were detected by staining with Coomassie Brilliant Blue R-250. A set of molecular mass markers was included in each gel.

Chemicals. Rennilase, a crude acid protease from Mucor miehei, was a gift from Novo Enzyme Corporation (Mamaroneck, NY, USA). UDP-GlcNAc, GlcNAc, 3,4-DNP-TNAC, Freund's adjuvants and the enzymeconjugated goat anti-rabbit IgG fractions were obtained from Sigma. Bio-Gels P-100 and A-5m, DEAE Bio-Gel A and most chemicals used for electrophoresis were purchased from Bio-Rad. ${ }^{14} \mathrm{C}$-labelled UDP-GlcNAc was obtained from ICN. All other chemicals were of the highest purity commercially available.

\section{RESULTS}

\section{Chitin synthase and chitinase activities during the growth cycle of $M$. rouxii}

Chitinase and chitin synthase activities were measured in whole-cell homogenates as a function of the growth age of $M$. rouxii. In this experiment, chitin synthase activity was measured by descending paper chromatography to account for diacetylchitobiose released from the nascent polymer by the endogenous chitinolytic activity. Chitinase activity was measured with the chromogenic substrate 3,4-DNP-TNAC, whose hydrolysis is quantitatively comparable to that of nascent chitin (Chagolla et al., 1987). As shown in Fig. 1(a), the specific activity of both enzymes was expressed in a parallel form, showing a peak in the mid-exponential phase of growth. When expressed as total activity in the extracts, both enzymes peaked at $12 \mathrm{~h}$ (not shown). The higher specific activity of chitinase detected in younger cultures was reproducibly observed in at least three experiments. In one independent experiment where only chitinase activity was measured, this was expressed maximally in $4 \mathrm{~h}$ cultures (Fig. 1b). This early expression of chitinolytic activity, probably involved in germination, was not investigated further since the primary purpose of the study was the analysis of the activity observed at the exponential phase of growth. On the basis of these findings, subsequent studies were done in $10 \mathrm{~h}$ cultures of the fungus.

\section{Purification of chitinases}

When the P-60 fraction of cytosol was subjected to gel chromatography in a column of Bio-Gel $P-100$, the lytic activity was separated into two peaks, I and II, which eluted slightly behind the major peak of UV-absorbing material. A typical elution profile is shown in Fig. 2. Most active fractions from both peaks were combined and concentrated by reprecipitation with ammonium sulphate as described in Methods. The resulting P-70 fraction was further purified by ionexchange chromatography in a column of DEAE Bio-Gel $\mathrm{A}$. The lytic activity again resolved into two peaks which eluted at about $0.23 \mathrm{M}$ (peak I) and $0.16 \mathrm{M}$ (peak II) $\mathrm{NaCl}$, respectively (Fig. 3). No chitinase activity was recovered in the buffer eluate, where most of the protein emerged as a single peak. The results of purification are summarized in Table 1. Chitinases I and 


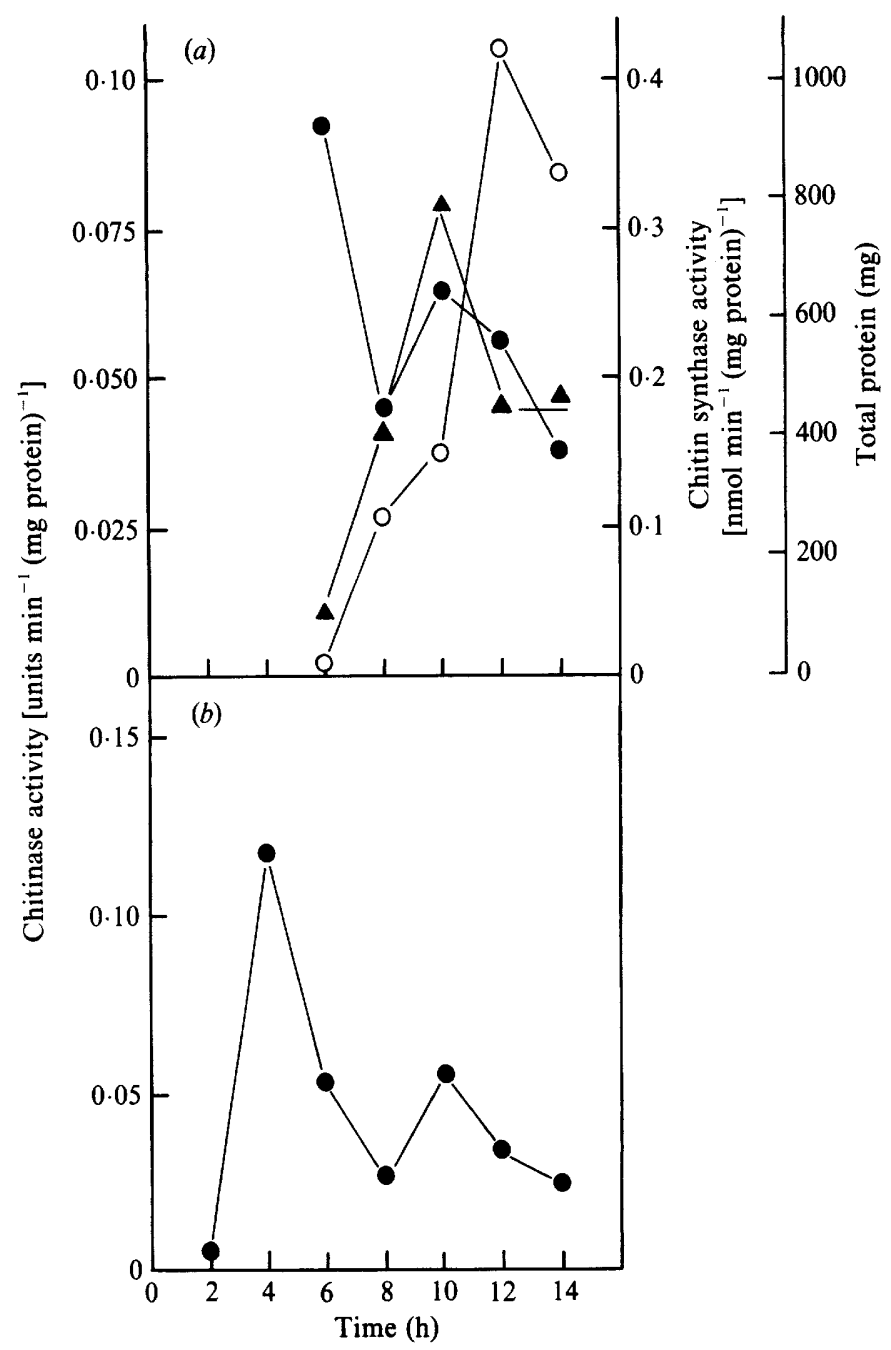

Fig. 1. Activities of chitinase and chitin synthase during the growth cycle of $M$. rouxii. (a) Activities of chitin synthase $(\boldsymbol{\Lambda})$ and chitinase $(\boldsymbol{\theta})$ were measured by descending paper chromatography and the chromogenic assay, respectively, in whole-cell homogenates of mycelium grown for the indicated times. The growth curve $(O)$ is expressed as total protein in the whole homogenate. In $(b)$ only chitinase activity was measured.

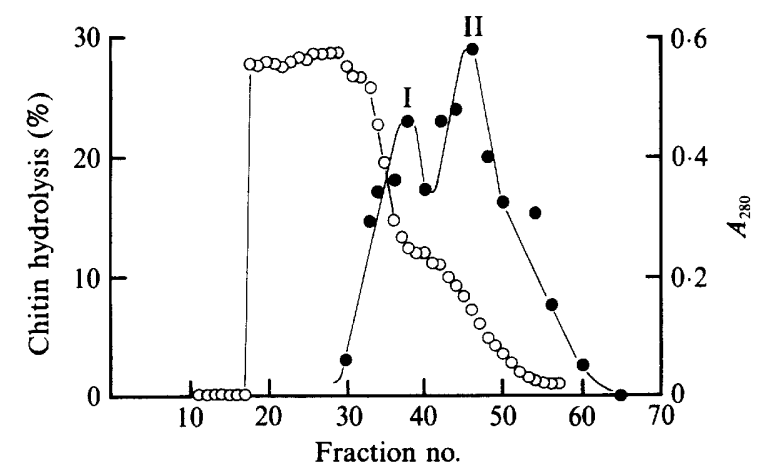

Fig. 2. Elution profile of chitinolytic activity in a column of Bio-Gel P-100. The P-60 fraction was subjected to gel chromatography as described in Methods. Chitinase activity on nascent chitin $(\bullet)$ and absorbance at $280 \mathrm{~nm}(O)$ were measured in fractions $(5 \cdot 0 \mathrm{ml})$. 


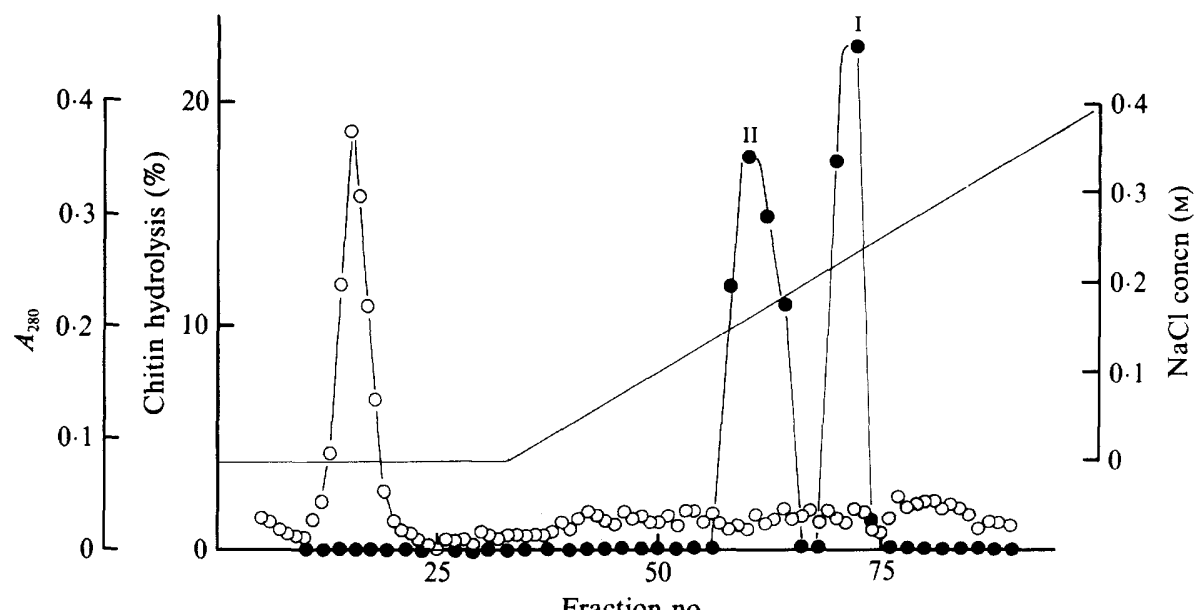

Fraction no.

Fig. 3. Separation of chitinases by ion-exchange chromatography. Active fractions from peaks I and II separated by Bio-Gel P-100 chromatography were pooled, concentrated by reprecipitation with ammonium sulphate and subjected to chromatography in a column of DEAE Bio-Gel A as described in Methods. Chitinase activity on nascent chitin (O) and absorbance at $280 \mathrm{~nm}(O)$ were measured in fractions $(5.0 \mathrm{ml})$.

Table 1. Purification of chitinases from $M$. rouxii

\begin{tabular}{lccccc}
\multicolumn{1}{c}{ Fraction } & $\begin{array}{c}\text { Total protein } \\
\text { (mg) }\end{array}$ & $\begin{array}{c}\text { Total } \\
\text { activity }\end{array}$ & $\begin{array}{c}\text { Specific activity } \\
\text { [units (mg protein) }\end{array}$ & $\begin{array}{c}\text { Purification } \\
\text { (fold) }\end{array}$ & $\begin{array}{c}\text { Recovery } \\
(\%)\end{array}$ \\
$\begin{array}{l}\text { Cytosol } \\
\text { P-60 }\end{array}$ & $844 \cdot 2$ & 12241 & 14.5 & 1 & 100 \\
$\begin{array}{l}\text { Bio-Gel P-100 } \\
\text { (Peaks I and II) }\end{array}$ & 486.4 & 10360 & 21.3 & 1.5 & 85 \\
$\begin{array}{l}\text { DEAE Bio-Gel A } \\
\text { Peak I }\end{array}$ & 24.6 & 8177 & 332.4 & 23 & 67 \\
Peak II & 0.49 & 2171 & 4430.4 & 305 & 18 \\
& 0.35 & 1873 & 5352.2 & 369 & 15
\end{tabular}

II were purified to about the same extent, i.e. 305- and 369-fold, respectively, after DEAE BioGel A chromatography. The procedure yielded a total recovery of chitinolytic activity of $33 \%$.

\section{Molecular masses}

The molecular masses of chitinases separated in the column of Bio-Gel P-100 were estimated by gel filtration in a calibrated column $(1 \times 148 \mathrm{~cm})$ of Ultrogel AcA 44 (LKB) equilibrated and eluted with PMB. For chitinases I and II, they were estimated to be 30.7 and $24.2 \mathrm{kDa}$, respectively.

\section{Purity of chitinase preparations}

The preparation of chitinase I obtained after ion-exchange chromatography was homogeneous, as judged by SDS-PAGE, with an estimated molecular mass of $30 \mathrm{kDa}$. When a sample of chitinase II was subjected to the same analysis, three bands were observed: a major one with a molecular mass of $25 \mathrm{kDa}$ and two minor polypeptides with molecular masses of 27 and $30 \mathrm{kDa}$ (results not shown).

Results from SDS-PAGE and chromatography in the Ultrogel column established the correspondence of chitinases of $30.7 \mathrm{kDa}$ (I) and $24.2 \mathrm{kDa}$ (II) separated in Bio-Gel P-100 with chitinases eluting at $0.23 \mathrm{M}$ (I) and $0.16 \mathrm{M}$ (II) $\mathrm{NaCl}$ from DEAE Bio-Gel A, respectively. 

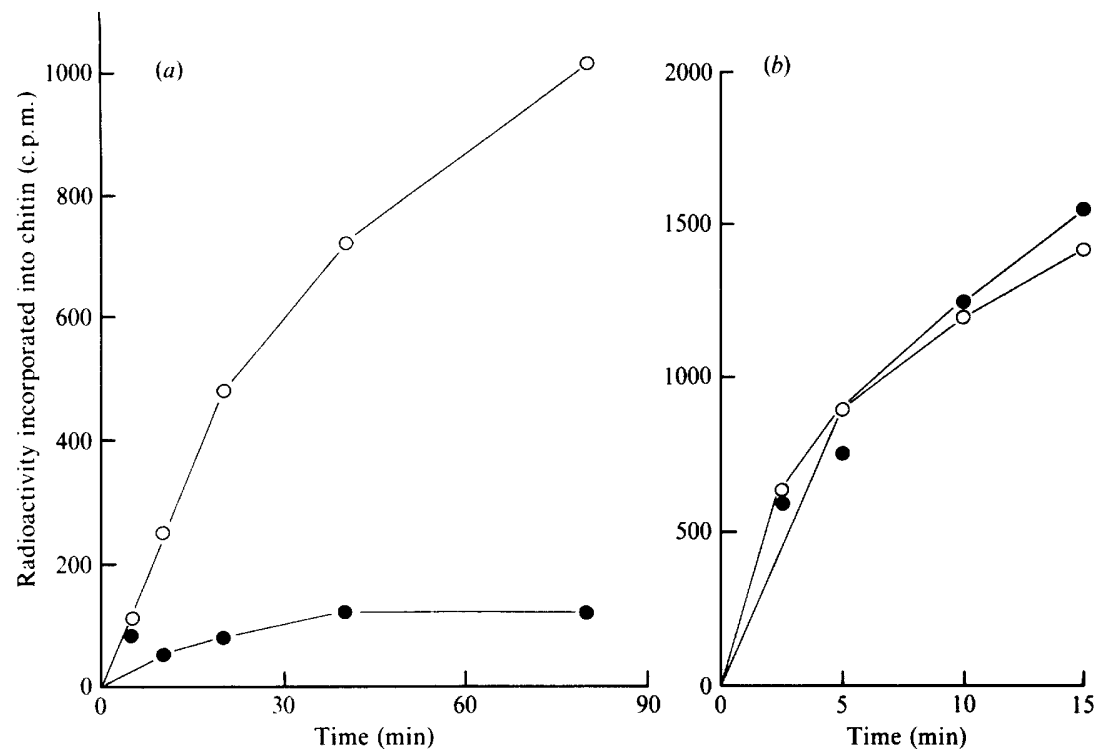

Fig. 4. Chitinolytic activity against nascent $(a)$ and preformed $(b)$ chitin. In (a), PMB (O) or P-70 fraction $(75 \mu \mathrm{g}$ protein) $(O)$ were added to standard chitin synthase assays at the start of incubation. At the indicated times, the radioactivity incorporated into chitin was measured as described in Methods. In $(b)$, standard mixtures for chitin synthesis were prepared in duplicate. After the indicated times of incubation, the mixtures were boiled for $5 \mathrm{~min}$. After cooling, a control sample received PMB $(O)$ and the other received chitinase I $\left(60 \mu \mathrm{g}\right.$ protein) $(O)$. After $30 \mathrm{~min}$ at $30^{\circ} \mathrm{C}$, radioactive chitin was measured by filtration, as described in Methods.

\section{Some properties of the chitinases}

The chitinases hydrolysed nascent chitin (i.e. the chitin being synthesized during a standard chitin synthase assay) more effectively than preformed chitin. As shown in Fig. 4(a), a high rate of chitin hydrolysis (more than $80 \%$ hydrolysed after $20 \mathrm{~min}$ ) was observed when P-70 fraction was added to chitin synthase assay mixtures at the start of incubation. When either chitinase I or II, separated in Bio-Gel P-100, was independently added to assay mixtures that had been incubated for different, short periods of time and had been boiled for $5 \mathrm{~min}$, digestion of the preformed chitin did not occur. Results for chitinase I are shown in Fig. $4(b)$. It is worth noting that in some experiments, the P-70 fraction hydrolysed chemically prepared $\left[{ }^{14} \mathrm{C}\right]$ chitin at a very low rate (less than $10 \%$ hydrolysed after $12 \mathrm{~h}$ ) when compared with hydrolysis of nascent chitin. Paper chromatography revealed diacetylchitobiose as the sole product of hydrolysis of nascent or preformed chitin, thus confirming previous results with chitinase from the yeast form of the fungus (Lopez-Romero et al., 1982). Other properties of chitinases such as $\mathrm{pH}$ and temperature optima for activity were determined in the P-70 fraction using the chromogenic assay with 3,4DNP-TNAC. Optima were pH 6.5 (with $100 \mathrm{mM}-\mathrm{KH}_{2} \mathrm{PO}_{4} / \mathrm{NaOH}$ buffer) and $30^{\circ} \mathrm{C}$ (under the assay conditions used), respectively. Heating of the $\mathrm{P}-70$ fraction for $15 \mathrm{~min}$ at $40^{\circ} \mathrm{C}$ and $50{ }^{\circ} \mathrm{C}$ resulted in losses of $25 \%$ and $85 \%$ in chitinolytic activity against nascent chitin, respectively.

\section{Antigenic relatedness between the chitinases}

The titre of antibodies to chitinase I in the IgG fraction of immunized rabbit serum was 1 in 64 as measured by the ELISA test. No immunoreaction was observed in control wells incubated with preimmune IgG fraction or when chitinase II was substituted for chitinase I as the antigen.

Specificity of antiserum was further analysed by the immunoblot technique using the peak fraction of either chitinase I or chitinase II separated in Bio-Gel P-100 as antigens. Results (not shown) confirmed the specificity of antibodies to the $30 \mathrm{kDa}$ chitinase. A faint band below the major one perhaps corresponded with a product of chitinase I proteolysis. 


\section{DISCUSSION}

The parallel expression of chitinase and chitin synthase activities during the growth cycle of filamentous cells of $M$. rouxii suggests that chitinolytic activity might be critical in fungal growth. Very similar results were obtained for Candida albicans by Barrett-Bee \& Hamilton (1984). The high specific activity of chitinase detected early during the growth curve of $M$. rouxii suggests its involvement in germination, a possibility which is currently under investigation.

There are few reports dealing with the purification of fungal chitinases (for a review see Cabib, 1987). The purification of these enzymes from cell-free extracts of $M$, rouxii as described here led us to the identification in the cytosol of two distinct forms of chitinase which have different molecular mass, ionic charge and immunological properties as judged by immunoblot and ELISA tests.

The existence of more than one form of chitinase has been described in other systems. In the hornworm Manduca sexta, chitinases have been separated by gel chromatography in three fractions with distinct electrophoretic properties. Chitinases I and III were glycoproteins. Chitinases I and II were immunorelated but not chitinase III (see Cabib, 1987). Tominaga \& Tsujisaka (1976) purified two chitinases (I and II) from the culture broth of Streptomyces orientalis. Serratia marcescens, a chitinase-producing bacterium, has been shown to produce five chitinase species with molecular masses ranging from 21 to $57 \mathrm{kDa}$ (Fuchs et al., 1986). Purified chitinase preparations from Saccharomyces cerevisiae resolved into several bands with chitinolytic activity after PAGE (Correa et al., 1982). This behaviour was attributed by the authors to the glycoprotein nature of the enzyme.

Chitinases I and II of $M$. rouxii had molecular masses of 30.7 and $24.2 \mathrm{kDa}$, respectively. These values are in agreement with those reported in the literature for chitinases from other systems, some of which group around $30 \mathrm{kDa}$ whereas others are in the 47-50 kDa range. Also, a $\mathrm{pH}$ optimum of 6.5 is common among chitinases (Cabib, 1987), although an unusually low $\mathrm{pH}$ optimum (1.5-2.5) has been described for chitinases from Saccharomyces cerevisiae (Correa et al., 1982).

In agreement with previous results (Lopez-Romero et al., 1982; Chagolla et al., 1987), nascent chitin was the preferred substrate for chitinases. Preferential digestion of nascent chitin over preformed chitin has also been described for chitinases from wheatgerm (Molano et al., 1979), Saccharomyces cerevisiae (Correa et al., 1982), Neurospora crassa (Zarahin-Herzberg \& ArroyoBegovich, 1983) and Serratia marcescens (Vermeulen \& Wessels, 1986). This behaviour is not restricted to chitinases. Other hydrolases such as chitin deacetylase (Davis \& Bartnicki-Garcia, 1984) and $\beta$-1,3-glucanase (Perez et al., 1984) act better on the corresponding nascent polymers. The physiological implications, if any, of the preferential breakdown of nascent over preformed chitin by chitinases is still a matter of speculation (Cabib, 1987).

The isolation of chitinases from the cytosolic fraction of $M$. rouxii does not necessarily mean that they are within the cytoplasm. In this context, chitinolytic activity has been detected in vacuoles and in the periplasmic space of Saccharomyces cerevisiae (Elango et al., 1982). In Neurospora crassa, chitinolytic activity was distributed in the cytosol $(55 \%)$ and in the cell-wall fraction $(30 \%)$ with little activity in the membrane fraction (Zarahin-Herzberg \& ArroyoBegovich, 1983). Polacheck \& Rosenberger (1978) also detected chitinolytic activity in the walls of Aspergillus nidulans. Humphreys \& Gooday (1984a) detected chitinolytic activity in a highspeed supernatant and in a microsomal fraction from Mucor mucedo. Interestingly, the particulate but not the soluble chitinase behaved as a zymogen and required a phospholipid environment for maximum activity (Humphreys \& Gooday, 1984b). Because these two properties are shared by chitin synthase, the authors proposed that microsomal chitinase and chitin synthase might be co-regulated to play a morphogenetic role in hyphal growth. In mycelial cells of $M$. rouxii, we have also observed chitinase activity in the cell wall and in a mixed membrane fraction (Chagolla et al., 1987). Further studies will be required to establish the physiological significance of multiple forms and locations of chitinases in $M$. rouxii and other organisms. 
Part of this work was supported by DIGICySA of the Subsecretaria de Educacion Cientifica, SEP, and the Consejo Nacional de Ciencia y Tecnologia, Mexico. Thanks are given to Dr Jose Ruiz Herrera for critical reading of the manuscript and Armando Obregon, Guadalupe Novoa and Alfonso Carabez for their help with the photographic work.

\section{REFERENCES}

BarRett-BeE, K. \& Hamilton, M. (1984). The detection and analysis of chitinase activity from the yeast form of Candida albicans. Journal of General Microbiology 130, 1857-1861.

BARTNICKI-GARCIA, S. (1968). Cell wall chemistry, morphogenesis, and taxonomy of fungi. Annual Review of Microbiology 22, 87-108.

BARTNICKI-GARCIA, S. (1973). Fundamental aspects of hyphal morphogenesis. Symposia of the Society for General Microbiology 23, 245-267.

BARTNICKI-GarcIA, S. \& LipPMAN, E. (1972). The bursting tendency of hyphal tips of fungi: presumptive evidence for a delicate balance between wall synthesis and wall lysis in apical growth. Journal of General Microbiology 73, 487-500.

BARTNICKI-GARCIA, S. \& NiCKERSON, W. J. (1962). Nutrition, growth and morphogenesis of Mucor rouxii. Journal of Bacteriology 84, 841-858.

CABIB, E. (1987). The synthesis and degradation of chitin. Advances in Enzymology 59, 59-101.

Chagolla, A., Pedraza, M. \& Lopez-Romero, E. (1987). Actividad quitinolitica en extractos libres de celulas miceliales de Mucor rouxii. Revista mexicana de micologia 3, 283-292.

Correa, J. U., Elango, N., Polacheck, I. \& Cabib, E. (1982). Endochitinase, a mannan-associated enzyme from Saccharomyces cerevisiae. Journal of Biological Chemistry 257, 1392-1397.

DAvis, L. L. \& BaRTNICKI-GaRCIA, S. (1984). Chitosan synthesis by the tandem action of chitin synthetase and chitin deacetylase from Mucor rouxii. Biochemistry 23, 1065-1073.

Elango, N., Correa, J. U. \& Cabib, E. (1982). Secretory character of yeast chitinase. Journal of Biological Chemistry 257, 1398-1400.

Engvall, E. \& PerlmanN, P. (1972). Enzyme linked immunosorbent assay (ELISA). III. Quantitation of specific antibodies by enzyme-labelled antiimmunoglobulin in antigen coated tubes. Journal of Immunology 109, 129-135.

Fuchs, R. L., McPherson, S. A. \& Drahos, D. J. (1986). Cloning of a Serratia marcescens gene encoding chitinase. Applied and Environmental Microbiology 51, 504-509.

GoOday, G. W., Humphreys, A. M. \& McIntosh, W. H. (1986). Roles of chitinases in fungal growth. In Chitin in Nature and Technology, pp. 83-91. Edited by R. Muzzarelli, C. Jeuniaux \& G. W. Gooday. New York: Plenum Press.

Hirano, S., Ohe, Y. \& ONo, H. (1976). Selective $N$ acylation of chitosan. Carbohydrate Research 47, $315-320$.

Humphreys, A. M. \& GoOdAY, G. W. (1984a). Properties of chitinase activities from Mucor mucedo: evidence for a membrane-bound zymogenic form. Journal of General Microbiology 130, 13591366.

Humphreys, A. M. \& Gooday, G. W. (1984b).
Phospholipid requirement of microsomal chitinase from Mucor mucedo. Current Microbiology 11, 187190.

LAEMMLI, U. K. (1970). Cleavage of structural proteins during the assembly of the head of bacteriophage T4. Nature, London 227, 680-685.

LoPez-Romero, E., Ruiz-Herrera, J. \& BartnickiGarCIA, S. (1978). Purification and properties of an inhibitory protein of chitin synthetase from Mucor rouxii. Biochimica et biophysica acta 525, 338-345.

LOPEZ-RoMero, E., RUIZ-HERRERA, J. \& BARTNICKIGarcia, S. (1982). The inhibitory protein of chitin synthetase from Mucor rouxii is a chitinase. Biochimica et biophysica acta 702, 233-236.

McMurrough, I. \& BARTNICKI-Garcia, S. (1973). Inhibition and activation of chitin synthesis by Mucor rouxii cell extracts. Archives of Biochemistry and Biophysics 158, 812-816.

Molano, J., Polacheck, I. \& Cabib, E. (1979). An endochitinase from wheat germ. Journal of Biological Chemistry 254, 4901-4907.

Perez, P., Garcia-Acha, I. \& Duran, A. (1984). $\beta(1,3)$-Glucanases from Geotrichum lactis: activity on its own nascent and preformed $\beta(1,3)$-glucan. FEMS Microbiology Letters 23, 233-238.

PolaCheCK, I. \& Rosenberger, R. F. (1978). Distribution of autolysins in hyphae of Aspergillus nidulans: evidence for a lipid-mediated attachment to hyphal walls. Journal of Bacteriology 135, 741-747.

ROSENBERGER, R. F. (1979). Endogenous lytic enzymes and wall metabolism. In Fungal Walls and Hyphal Growth, pp. 265-277. Edited by J. H. Burnett \& A. P. J. Trinci. Cambridge: Cambridge University Press. Ruiz-Herrera, J. \& Bartnicki-Garcia, S. (1976). Proteolytic activation and inactivation of chitin synthetase from Mucor rouxii. Journal of General Microbiology 97, 241-249.

TominaGa, Y. \& Tsujisaka, Y. (1976). Purifications and some properties of two chitinases from Streptomyces orientalis which lyse Rhizopus cell wall. Agricultural and Biological Chemistry 40, 2325-2333.

Towbin, H., Staehelin, T. \& GoRdon, J. (1979). Electrophoretic transfer of proteins from polyacrylamide gels to nitrocellulose sheets: procedure and some applications. Proceedings of the National Academy of Sciences of the United States of America 76, 4350-4354.

Vermeulen, C. A. \& Wessels, J. G. H. (1986). Chitin biosynthesis by a fungal membrane preparation. Evidence for a transient non-crystalline state of chitin. European Journal of Biochemistry 158, 411415.

Wessels, J. G. H. (1986). Cell wall synthesis in apical hyphal growth. International Review of Cytology 104, 37-79.

Zarahin-Herzberg, A. \&. Arroyo-Begovich, A. (1983). Chitinolytic activity from Neurospora crassa. Journal of General Microbiology 129, 3319-3326. 